\title{
Ethnoichthyological knowledge and perception in traditional medicine in Ondo and Lagos States, southwest Nigeria
}

\author{
JO Orilogbon \& AM Adewole
}

Department of Environmental Biology \& Fisheries, Adekunle Ajasin University, Akungba Akoko, Ondo State, Nigeria.

\begin{abstract}
Fish are an important source of food and commerce, and of immense benefit for their nutritional qualities and other various applications such as biopharmaceutical drugs, oil, rituals, festivals, ceremonies and leather. Ethnomedical applications of fish are most prevalent among the Yoruba clan of Nigeria in West Africa, and in other parts of the world. We review here knowledge of ethnoichthyology and applications in Lagos and Ondo states. One hundred and twenty participants (rural- and urban-based traditionalists, fish farmers, and herb sellers) were surveyed. Clarias species had the highest usage (48\% of uses) followed by Malapterurus electricus (15\%). Fish were used for healings, rituals, sacrifices, ceremonies and festivals. They were reported to be used with plants, inanimate objects and various odu ifa (incantations) based on their physical and spiritual endowments. Of 179 recipes, $23 \%$ were fish alone, while others used different parts of the fish with other materials.
\end{abstract}

Keywords: odu/ ese ifa (ifa corpus), incantation, recipes

\section{Introduction}

Apart from the nutritional value of plants and animals, they also have traditional and medicinal values which make them important among those who know about them (Banjo et al. 2004). From ancient times, plants and animals have been used for curative purposes in medicine (Lev 2003; Yeisilada 2003; Alves 2006; Mafimisebi \& Ogunlade 2009) and in modern times they continue to play an essential role in health care (Chivian 2002; Adebisi 2009). It is widely accepted among traditional healers that the presence of active constituents from plants can be used for healing along with active ingredients from fish. Examples of such plants are Dalbergia lactea, Piper guineense and Ocimum gratissimum, commonly used in southwest Nigeria for various illnesses. According to Adebisi (2009), the basic elements needed in traditional medicine are bioresources and other inanimate objects found in the environment.

The pharmacopeias of folk medicine as well as professional medical systems like Ayurveda, Unani and biomedicine contain thousands of medicines made from leaves, herbs, roots, barks, mineral substances and other materials found in nature (Good 1980; Gesler 1992). New anti-malaria drugs were developed from the discovery and isolation of artemisinin from Artemisia annua L, a plant used in China for almost 2000 years (WHO 2008). In Western Europe the use of traditional medicinal plants is thriving: $70-80 \%$ of the population depends on alternative medicine and annual revenues reached US \$ 5 billion in 2003-2004 (WHO 2010). $80 \%$ of African populations depend on traditional medicine, but their systems are largely a mystery to the western world. Traditional medicine in Nigeria is a form of healthcare system, and remains the commonest source of healthcare after self-treatment (Rhymey 2008). Yoruba religion uses a system of divination called Ifa, embodied in a literary corpus known as the Odu Ifa, and fish are used in some parts of these practices.

Ethnoichthyology is the use of fish by indigenous people for their immediate needs, such as food and traditional medicine. Fish can therefore be used by Ifa priests as objects for idol worship, spiritual rites and also native medicine for healing (Ogunleye, personal communication 2007). Ethnoichthyology is commonly used among traditional healers for the 
sealing of agreements, and appeasing and invoking of traditional gods (Sowumi 2007; Awolalu 1981).

The traditional medical practices of the Yoruba in Nigeria however offer a fresh outlook on health concepts, and unique healing treatments to the world medical community (Olson \& Nkiwane 2006). The use of fish in healing practices by the Ilajes in Ondo and Lagos States in southwestern parts of Nigeria is presented here to broaden current perspectives of healing practices (cf. Sowumi 2007).

\section{Materials \& Methods}

A survey was carried out in which 120 structured questionnaires were administered to ruraland urban-based traditionalists, herb traders (elewe omo) and older people who have knowledge of ethnoichthyology. The surveyed areas were Ilaje in Ondo State (comprised of the Ilaje/Ese Odo local government area), Igbokoda, Ugbo, Fagbin and Araromi; and areas in the Lagos state comprising Amuwo Odofin, Alimosho and Ajeromi-Ifelodun local government areas, Egan, Igando, Agboju, Ijora-Badia, Festac and satellite towns. Traders and practitioners were consulted for the indigenous names of fish. Synonyms arising from language/dialect were clarified using a chart from the Nigeria Institute of Oceanography \& Marine Research.

In this study, the recipes used for different ailments were recorded through interacting with practitioners, so as to understand the precise role of each species and their efficacy. The use of fish in socio-cultural practices such as spiritualism, ceremonies and other sacrificial rites were also studied.

\section{Results}

Most of the people interviewed were 41-50 years of age, the majority of whom were married Christian men who were traditional medical practitioners (58\%). Some fish species are used for healing ailments without the use of incantations (Table 1). Out of the five species used in this way, the commonest was Clarias spp (46\%), followed by Malapterurus electricus (23\%), Oreochromis niloticus (15\%), Heterobranchus (8\%) and Polydactylus quadrafilis (8\%). Sometimes fish are used with incantations (Table 1) during healing of various ailments: again Clarias spp were commonly used (50\%), followed by Malapterurus electricus (20\%) and Heterobranchus, Oreochromis niloticus and Parachanna obscura with $10 \%$ each.

Fish are also used during festivals and ceremonies (Table 1), and again Clarias spp dominated (55\%) followed by Polydactylus quadrafilis (18\%), with Heterobranchus, Heterotis niloticus and Synaceia verrucosa (9\% each). Fish species that have taboos associated with them (Table 1) include Synaciea verrucosa and Xiphia gladius. The latter species is forbidden by the Ogbaro clan in Ilaje (Ondo State) because they believe it represents their ancestral forefathers, and anyone family member that eats it will die.

Fish species used in rituals and sacrifices in conjunction with odu/ese ifa are most commonly Clarias species: live fish bring protection (ejiogbe), whilst dried fish form the covenant and sealing of an agreement (no odu/Ese ifa name). Heterobranchus spp are less used, live fish bringing good fortune (owonrin).

The overall proportion of usage showed that Clarias spp is the most common (48\%), followed by Malapterurus electricus (15\%), Heterobranchus spp (10\%), Polydactylus quadrifilis (8\%), Oreochromis niloticus and Synaciea verrucosa (5\% each) and Parachanna obscura, Heterotis niloticus and Xiphias gladius (3\% each). 
Table 1: Uses of fish in traditional healing

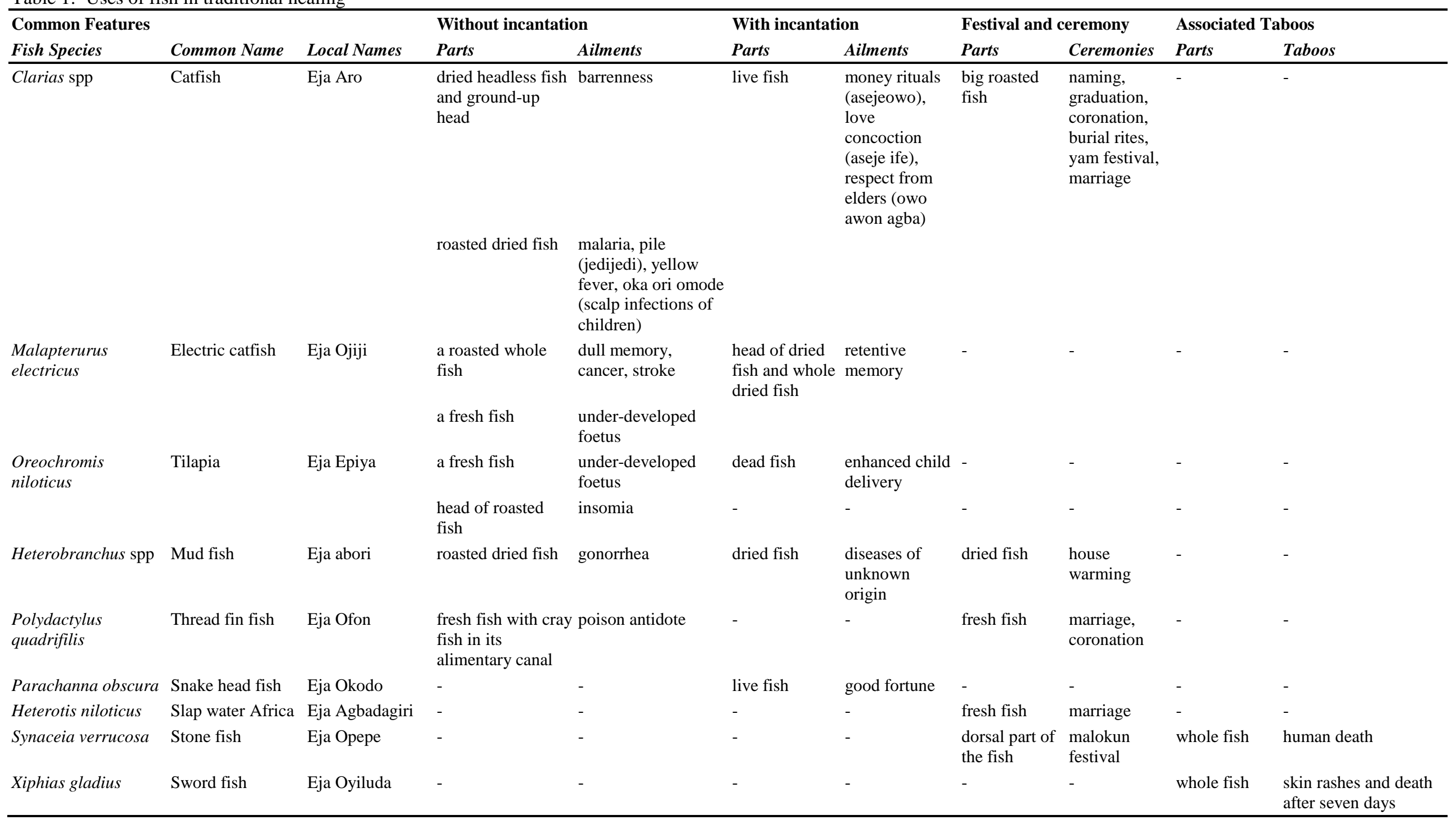


Table 2: List of some of the plant and other materials utilized together in various recipes (fish components not included)

\begin{tabular}{lllll}
\hline plant species & part & local names & other materials & local names \\
\hline Gongronema latifolium & leaves & Ewe Daji & Potash & Kawun- bilala \\
Peperoma pellucida & leaves & Ewe Rinrin & Palm kernel oil & Adin \\
Alternanthera sessilis & leaves & Ewe rekureku & Palm oil & Epo pupa \\
Ocimum gratissimum & Leaves & Ewe Efinrin & Sweet & Adun \\
Gongronema latifolium & Leaves & Ewe Iteji & Dry crayfish & Ede Gbigbe \\
Senecio abyssinicus & Leaves & Ewe Amunimuye & Liquor of snail & Omi Igbin \\
Uraria picta & Leaves & Ewe alupaida & Salt & Iyo \\
Spondias mombin & Leaves & Ewe Iyeye & Lagoon sand & Iyepe eti osa \\
Dalbergia lacteal & Leaves & Ewe ojiji & Honey & Oyin \\
Senna alata & Leaves & Ewe Asunwon & Locust bean & Iru woro \\
Markamia tomementosa & Bark & Igi Olode & Palp & Ogi \\
Socoglottis gabinensis & Bark & Itala & Groundnut oil & Ororo \\
Coco nucifera & Bark & Epo Agbon & Urine & Ito \\
Piper guineense & Seed & Ata Iyere & water & Omi tutu \\
Baphia nitida & Root & Idi igi Orosun & Cow liver & Edo malu \\
\hline
\end{tabular}

Table 2 records some of the plant materials and the various other materials used together. Some of the plant materials are ground up fresh, or sun-dried and then combined with the other materials.

\section{Discussion}

The regional distribution of the respondents covers largely the rain forest and swamp region of the country, where most of the native plant, animals and fishes are found. The surveyed area ranges from densely populated areas of Lagos state to more moderately populated areas of Ondo State. The gender distribution shows more males than females in the profession of traditional medicine, perhaps because transfer of the knowledge between generations occurs to boys, and only in rare circumstances to girls. Traditional medicine is seen as a family inheritance, to be preserved down the generations.

In the light of modern-day technological knowledge, a sharp transition from the former crude ways of preparing concoctions are beginning to emerge via process development protocols; this tends to render obsolete the African way of doing things. Some of the factors that have affected ethnoichthyological knowledge in this part of Nigeria include modernisation and increased level of literacy, adoption of western orthodox medical practices, the loss of information when it fails to be transmitted among generations, social vices, non-patronage, societal relegation and cultural loss.

Plants and animals have been used by man from his immediate environment from the early Stone Age, gradually becoming a structured methodology for medicinal, nutritional and other socio-economic purposes (Gbile 1985). The synergies of using other organisms with different fish species affirms that over the years man has succeeded tremendously in his understanding of the scientific bases for their use. Table 2 shows a vivid example, with cow liver utilised along with Baphia nitida root.

Clarias species had the greatest range of utilization. All the traditionalists, fish farmers and herb sellers refers to Clarias as having numerous applications in traditional medicine, including the treatment of ailments and the making of sacrifices, rituals, festivals and ceremonies. The reasons given by the respondents for the use of fish in healing, ceremonies, rituals and the associated taboos vary from place to place. Meheshown (1998) showed that the 
type of wild and domesticated plants that people utilize for their comfort varies from place to place, and from one ethnic group to another.

There are different methods of preserving fish, including smoking, salting, drying and freezing. Fish preserved with any of the above mentioned methods can be used during the treatment of ailments. Smoked dried fish are widely used among the Ilajes and other coastal areas of the two states in the treatment of ailments, while live fresh fish were widely used for rituals and sacrifices. Fishes used in ceremonies can be fresh, smoked or fried depending on the occasion. Several authors (Asibey \& Child 1990, Sodeinde \& Soewu 1996, Ogunfeyibo 1998) have reported the traditional use of wildlife for the prevention of accidents, preparation of aphrodisiacs, fertility medicine for women and potency medicine for men. Here we also found such uses: Clarias spp, Oreochromis niloticus and Malapterurus electricus are used in the preparation of pre-natal and post-natal soup, and for infertility problems. Not less than $85 \%$ of respondents confirmed this fact. Clarias species and Malapterurus electricus are used in the treatment of insanity and cancer, respectively.

Fish are important in curing some ailments because they contain active ingredients, the essential fatty acids known as omega-3 fatty acids, typically including eicosapentaenoic acid and docosahexaenoic acid. These fatty acids are converted by the body into beneficial series- 3 prostaglandins. Fish liver oils contain vitamins A and D and may have a different concentration of eicosapentaenoic acid and docosahexaenoic acid than those derived from the flesh of the fish (Ray 2010). This explains why they are widely used by traditional healers in the coastal region.

Sahelia (2010) reported that traditional healers add herbs to the fish oil. In Yoruba land, oil palm is referred to as "ero", which means antidote. Since the major reason for using the fish is not just consumption, the oil in the fish does the healing by mixing with the herbs used along with it. 'Mind Power booster' made from fish-oil supplements helps memory, mood, mental clarity, concentration and alertness (Sahelia 2010). This supports the reason traditional healers suggest that smoked Malapterurus electricus fish can be used for 'Ogun isoye' (retentive memory, or sound mind). Others believe that incantation will make it work faster: "Iye mi pada si mi lokan, amunimuye da iye mi pada", which means that retentive memory return to my heart, the leaf Senecio abyssinicus return my memory. This is because the fish and leaves together used with other materials are believed to improve alertness.

The potent herb and nutrient mixture called 'Passion $\mathrm{Rx}$ ' is a combination of fish oil and other herbs, found to be useful as a sexual enhancement (Sahelia 2010). During this research, traditional healers mentioned the importance of Clarias spp in the curing of barrenness. The treatment was referred to as 'ETU INU', meaning 'calmness of the stomach'. The Clarias fish, roasted without salt, is used along with plant materials such as Ewe daji (Gongronema latifolium), Ewe ririn (Peperoma pellucida), Ewe rekureku (Alternanthera sessilis), the bark of the olode tree (Markamia tomentosa) and the bark of the Itala tree (Socolotis gabnensis).

Clarias fish was found to be used to cure insanity. Fish oils are beneficial for mental health (Sahelia 2010), although traditional healers believe that Clarias fish and herbs will work faster with incantation. The material needed includes three roasted fish ground up with Ewe rohun (Amphimas pterocarpoides), Ewe sobidire and ata ijosi (Capsicum frutenscens): all are cooked in the local pot with added salt and palm oil, to be eaten at once. The recipe with incantation has the material also in powdered form known as agunmu, comprising Iyere (Piper guineese) grounded up with Agunmona (Culcacida scanden) and legun loko (Psorospermum corymbferum). The patient is expected to add it to palp (Ogi/Eko) in the morning and at night, and to recite the following incantation: "Agunmona ki roju gun igi ja, iyere yoo gun igi ja, ti igi t'ope ni maa teribia fun iyere loko, ohun tin se emi (oruko alaisan) ko terbia fun mi" (Agunmona does not get to the top of the tree but iyere does; all the trees in the farm including palm bow down to iyere; here, all my sickness should bow to me (name of patient) today). 
There are many other ailments that have been researched and fish found to be useful treatments. Fish are also used in the sealing of agreements by those in occult groups. An example is Heterobranchus spp, together with other materials including kola nut (Kola acuminata) and roasted rat. All are placed in a calabash. At the point of agreement, participants recite the following incantation: “Agbor'ile a j'eku, agbor'ile aje eja, agbor'ile ogbodo dami, ase dowo ile tajo mu" (on the earth we ate rat together, on the earth we ate fish, on the earth you must not betray me, authority belongs to the earth).

Clarias spp were found to be used as sacrificial elements. For example, Orunmila, a deity, loves Eja aro (i.e. Clarias: Awolalu 1981). When sacrificing against an enemy, the person is told to get a live fish and recite the following incantation: "A dadi igbin, igbin ku, a dadi ekolo ekolo rorun alakeji a dadi aro aro we lo" (when the snail was broken it dies, when the earthworm is cut into two it dies, but when the catfish was cut into two it swims away). This implies that such a person will escape from all the threats of enemies (personal communication). By the play on words, parts of the names of the constituents transform the verse to activate the effects desired of the medium (Verger 1976, Mafimisebi \& Oguntade 2009).

Malapterurus electricus was found to be useful in the curing of cancer. The risk of advance prostate cancer may be reduced by intakes of eiocosapentaenoic and docosahexaenoic acid. Other ailments such as malaria, yellow fever, piles, stroke and other diseases of unknown origin may be cured.

95\% of the people in Ilaje confirmed the existence of taboos associated with a particular fish, Synaciea verrucosa - the stonefish, which is generally worshipped but is not to be eaten. The Ogbaro clan from Ilaje local government area also confirmed the fact that none of the family members, home or abroad, should eat swordfish (Xiphias gladius). Any member who eats the fish will have rashes all over their body, and if the person is not cured within seven days, he or she may die (personal communication).

The issue of the dwindling number of recipies available for natural healing practices has received worldwide attention, but the proposed solution is limited to plants and terrestrial animals (Anadu et al. 1980, Taylor \& Fox 1992, Adekoya 1983.

The concept of ethnoichthyological knowledge in western Africa in the light of emerging western technology and product development tends to downplay African indigenous methods and recipies. Of course, scientific advances in general tend to erase knowledge acquired by trial and error, even though for the native African orthodox, some level of divination is involved which goes beyond all form of scientific understanding. In China and India, traditional medicine and knowledge of ethnoichthyology has been successfully incorporated into modern medicine, enabling global acceptance of the resulting products. Global acceptance of native African ethnoichthyological knowledge will require the secrets of divination involved, and the mixtures currently kept within family lineages, be made accessible, enabling others to test and use it, facilitating its incorporation into technological medicine.

This research has shown the importance of fish in traditional healing, rituals, sacrifices, ceremonies, festivals, and the Odu ifa / ese ifa, and the reasons for using them. It has also shown how plant and other materials are added into recipes together with fish. The precise role of these fish has been difficult to understand until now. The spiritual reasons for the use of fish for protection, respect for elders, treatment of insanity and preparation for love concoctions was confirmed. Clarias spp have the most frequent and most widespread use, in almost every facet of traditional medicine. Nutritional biologists also reported that it has high levels of protein. More investigation should be carried out with practitioners on the treatment of ailments using odu/ese ifa or incantations, practices not restricted to Yoruba/ Africa alone, but also reported to be practised by the aborigines of Australia, Amerindians and various Asian peoples. Several recent studies show that people prefer medicines of natural origin. It is certain 
that Nigerians possess a wealth of knowledge about traditional medicine that must be tapped, studied and documented soon, before it is lost forever (Adebisi 2009). There should be increased public awareness of the tremendous value of traditional medicines, and this includes the use of fish and other materials.

\section{Acknowledgements}

We thank Dr FA Gbore and Dr O Oginni (Department of Environment \& Fisheries), Dr Olajubu (Department of Microbiology, Adekunle Ajasin University, Akungba Akoko, Ondo State) and Mr EO Ojo (Kingston University, London) for reviewing this work. Our sincere appreciation to Dr Ogunleye (Department of Religious Studies, Adekunle Ajasin), all the herb sellers, traditional healers, fishermen and the Ogbaros clan for their cooperation in making this work a success. Finally we thank people who contributed to this work whose names cannot be mentioned.

\section{References}

Adebisi LA (2009) Nature's Pharmacy in man's immediate environment: implication for primary health care delivery. 2008/2009 Faculty lecture, Faculty of Agriculture \& Forestry, University of Ibadan, Nigeria. 59 pp

Alves RRN \& Rosa IL (2006) From cnidarians to mammals: the use of animals and remedies in fishing communities in North Brazil. Journal of Ethnopharmacology 107: 259-276

Anadu PA, Elamah PO \& Oates JF (1980) The bush meat trade in southwestern Nigeria. Human Ecology 16:199208

Asibey EOA \& Child GS (1990) Wildlife management for ritual development in sub-Saharan Africa. Unasylva 41: $3-10$

Awolalu JO (1981) Yoruba belief and sacrificial rites. $2^{\text {nd }}$ edition. Longman, UK. 8:143-161; 9:162-167.

Banjo AD, Lawal OA, Olubanjo OA \& Owolana OA (2003) Ethnozoological knowledge and perception of the value of insects among the Ijebus (southwestern Nigeria). Journal of Pure \& Applied Science 1-6.

Berlin B (1992) Ethnological classification: principles of categorization of plants and animals in traditional society. Princeton University Press, New Jersey, 335 pp.

Berlin B, Breedlove DE \& Raven PH (1973) General principles of classification and nomenclature of folk Biology. American Anthropologist 75: 214-242

Chivian E (2002) Environment and Health. 7 Species loss and ecosystem distribution - the implications for human health. Canadian Medical Association Journal 164(1): 66-69

Gbile ZO (1985) Nigerian medicinal plants. Paper presented at the $26^{\text {th }}$ annual Conference of the Science Association of Nigeria, Port Harcourt, Nigeria.

Gbile ZO (2002) Vernacular names of plants: Yoruba. $2^{\text {nd }}$ edition, Forestry Research Institution of Nigeria, Ibadan.

Gesler WM (1992) Therapeutic landscapes: medical issues in the light of the new cultural geography. Social science \& medicine 34(7): 735-746

Good C (1980) Ethno-medical systems in Africa and LDCS key issue in medical geography. pp 93-116 in Conceptual and methodological issues in medical geography. http://en.wikipedia.org/wiki/Nigeria, accessed date $14 / 07 / 2011$

Lev E (2003) Traditional healing with animals (zoo therapy): medieval to present-day Levantine practice. Journal of Ethnopharmacology 80: 107-118

Mafimisebi TE \& Oguntade AE (2009) Socio-cultural and magic religion practiced and economic consideration in the formulation and use of plant medicine for human health management in southwest Nigeria. Proceedings of the Humboldt Kellogg Annual Conference, Federal University of Technology, Akure, Nigeria. $24^{\text {th }}$ April, pp. 243-249.

Mesheshwon O (1998) Ethnobotanical reseach and commendation. Systematic Botany 207-217

Ogunfeyibo FB (1998) Ethnozoological use of wildlife. A seminar in the department of Biological Science, Ogun State University, Ago Iwoye, pp 10-22.

Oslon J \& Nkiwane S (2006) Integrate for efficiency: traditional Yoruba medicine http:// www.coloradocollege. edu/academics/fye/essays/jolsonfall2006.pdf). 4 pp

Sahelian R (2010) Fish oil supplements: health benefits, side effects, omega-3 epa and dha, use for depression, heart disease and vision. Karolinska University Hospital, Huddinge, Stockholm.

Rhymey J (2008) Traditional medicine in Nigeria. A journal of Local medicine 1:1.

Sodeinde OA \& Soewu DA (1996) An ethnozoological survey of wild animals used in traditional medicine by a sub-urban community in south western Nigeria, and implication of the trade in sustainable resources. Paper of natural resources and community participation 24-27. June 1996: Harare, Zimbabwe

Sofowora A (1993) Medicinal plants and traditional medicine in Africa. $2^{\text {nd }}$ edition. University Press, Ibadan. 
Sowumi AA (2007) Fin fishes in Yoruba natural healing practice from southwest Nigeria. Journal of Ethnopharmacology 113: 72-78

Verger PF (1976) The use of plants in Yoruba traditional medicine and it linguistic approach. Seminar Paper delivered at a conference on 'Traditional medicine in Yoruba land' in the Department of African Languages \& Literature, University of Ile-ife, Nigeria, October, $\mathrm{p} 8$.

Wakeman CA (2004) A dictionary of Yoruba Language. University Press, Ibadan.

World Health Organisation (2008) Traditional medicine strategy. Fact sheet 134 (1-2)

Yesilada E (2005) Past and future contributions of traditional medicine in the healthcare system of the Middle East. Journal of Ethnopharmacology 100(1-2): 135-137

الملخص العربي

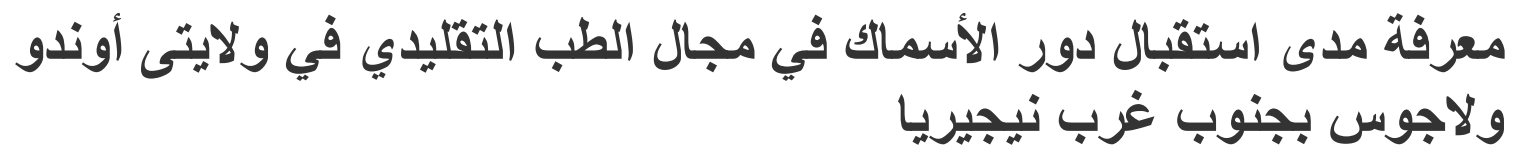

أوريلوجبون \& أدول

قسم البيولوجي البيئي و المصايد، جامعة أدكونل أجاسين، أكنجبا أكوكو، ولاية أوندو، نيجيريا

تعد الأسمالك مصدر آ هامأ للغذاء و التجارة وهى ذات فائدة كبيرة نظر آ لخصائصها الغذائية

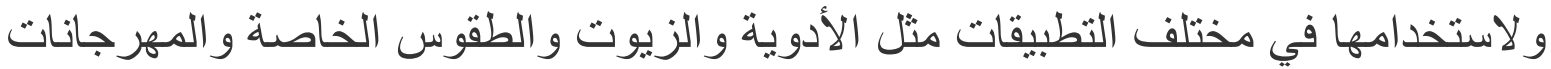

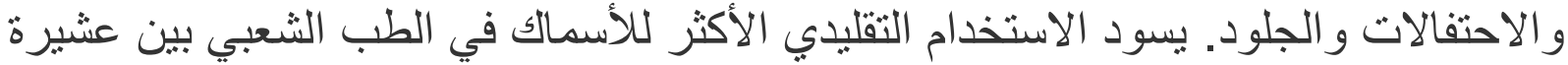

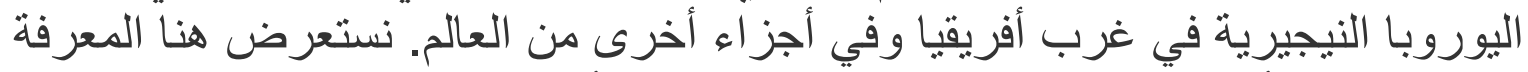

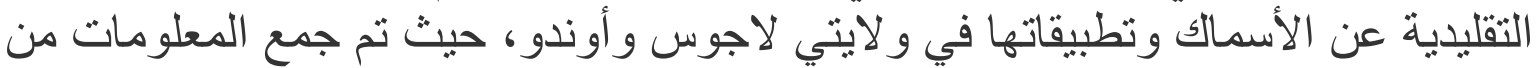

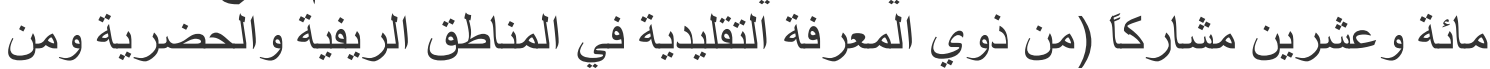

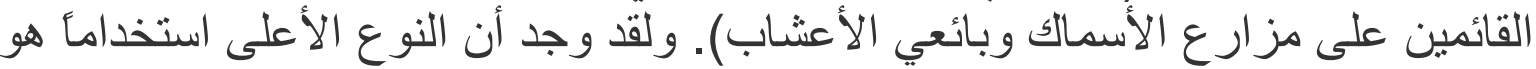
الكلاريس Clarias (48 ٪ من إجمالي الاستخدامات) ، يليه سمكة الر عاد electricus

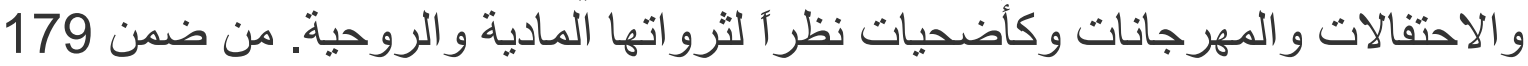
وصفة علاجية وجد 23 \% منها تعتمد على الأسمالك وحدها في حين تستخدم الوصفات الأخرى أجز اء مختلفة من الأسمالك مع غير ها من المو اد. 